\title{
Joanna Bielecka-Prus
}

Katedra Badań nad Kulturą i Komunikacja

Instytut Socjologii UMCS

ORCID: 0000-0001-7748-9156

$29 / 2020$

Political Dialogues

DOI: http://dx.doi.org/10.12775/DP.2020.018

\section{Persona anthropologica w terenie badawczym. Analiza wybranych narracji etnograficznych}

\begin{abstract}
:
In the fieldwork ethnographers play roles in different interactions and the roles are associated with the roles of others. Study of individuals is a relational, dynamic process and the gained knowledge is the objectivized result of this interaction. The researcher must constantly negotiate his/her place in the field, because the subjects are trying to embed the ethnographer in a variety of roles, shaped by macrostructural and situational factors. The article analysis the process structures, which takes place in the research, in particular typifications, institutional expectations and orientations, action schemes, and turning points. The analytical material are selected example of narrative ethnography genre.
\end{abstract}

Key words: narrative ethnography; fieldworks; roles of anthropologist

Słowa kluczowe: narracja etnograficzna; badania terenowe; role antropologa

\section{Wstęp}

Trudno nie zgodzić się z tezą, która głosi, że etnografia tworzona jest w procesie badawczym, który polega na zbieraniu danych podczas bezpośrednich i zwykle długotrwałych relacji etnografów z badanymi, w których i badacz, i badani są aktywnymi podmiotami różnorodnych interakcji. Rezultatem tych badań są etnograficzne opisy kultur w formie raportów, artykułów czy książek. Zatem tym bardziej może dziwić fakt, że zazwyczaj antropolog bywa w tych tekstach niewidoczny, jego aktywności badawcze i poza badawcze są ukryte przed czytelnikiem, który z trudem i jedynie w ogólnych zarysach, może rekonstruować przebieg działań podejmowanych przez etnografa. Wiadomo, że badacz był „tam”, ale nie wiadomo dokładnie co robił ${ }^{1}$. W niektórych pracach (jak np. w „Nuerze" Edwarda Evansa-Pricharda) badacz pojawia się jedynie w przedmowie, przede

${ }^{1}$ P. Collins, A. Gallinat, The Ethnographic Self as Resource: An Introduction, w: The Ethnographic Self as Resource: Writing Memory and Experience into Ethnography, red. P. Collins, A. Gallinat, Oxford 2010, s. 2. 
wszystkim po to, aby wzmocnić swoją pozycję eksperta i wiarygodność przedstawionych wywodów, dając świadectwo swojej obecności w terenie badawczym² ${ }^{2}$ Zwykle informacje te dotyczą czasu trwania badań, ich miejsca, zwięzłego opisu przebiegu badań z podkreśleniem trudności, z jakimi antropolog musiał się zmierzyć (np. problemy z dotarciem, niechęć tubylców, biurokracja, przebyte choroby, zamieszki itp.). W kolejnych częściach raportów antropologicznych badacz staje się niewidzialnym, acz wszystkowidzącym narratorem, co tekstualnie wyraża się w nieosobowych formach czasowników lub trzecioosobowych form czasownikowych opisujących działania obserwowanych osób. Ta nieobecność autora jest ważnym zabiegiem retorycznym, utwierdzającym czytelnika w przekonaniu, że ma do czynienia z obiektywną nauką, niezakłóconą czynnikami subiektywnymi czy personalnymi. Faktycznie cieleśnie obecny w polu badawczym etnograf zamienia się w tekstach w subtelny i duchowy byt, przenikający sieci znaczeń i struktury umysłów tubylców.

Dopiero w latach 70. i $80 \mathrm{XX}$ wieku zwrot postmodernistyczny i kryzys reprezentacji, związany z podważeniem tezy o obiektywności i neutralności procesów poznawczych od społecznych, historycznych i ideologicznych kontekstów, a także zwrot literacki, który postulował przemieszczanie się form i treści w ramach „zmąconych gatunków” sprawił, że coraz częściej pojawiały się eksperymentalne formy pisania i autoetnograficzne projekty w których badacz, jego działania, emocje i relacje społeczne, były tematyzowane i poddawane analizie ${ }^{3}$. Jednakże już dużo wcześniej pojawiły się prace antropologiczne, zwiastujące kryzys reprezentacji, w których doświadczenia badacza w polu badań były głównym wątkiem narracji. I nie chodzi tu jedynie o słynny Dziennik w ścisłym znaczeniu tego słowa, napisany przez Bronisława Malinowskiego w latach 1917-18 i opublikowany pośmiertnie w 1967 roku w atmosferze skandalu. Można bowiem założyć, że Malinowski nie planował wydania swoich prywatnych notatek w tej formie. Mam tu na myśli teksty, które w całości lub w dużej części poświęcone są refleksyjnej analizie praktyk badań terenowych ${ }^{4}$.

Dlaczego etnografowie pisali książki, które należały do „gatunków zmąconych”, łączących cechy relacji podróżniczej, autobiografii i tekstu etnograficznego w klasycznej jego formie? Badacze mogli uznać, że ich doświadczenia w terenie badawczym będą cenną wskazówka dla kolejnych, wyruszających w teren etnografów. Choć nie były to typowe podręczniki metodologiczne, zgodnie z zasadą verba docet, exempla trahunt do dziś stanowią bardzo dobre materiały dydaktyczne dla studentów. Być może także autorzy tekstów uznali, że używanie spersonalizowanej formy narracji usprawni budowanie wspólnoty między narratorem i adresatem, „wciągając” niejako odbiorcę w opisywane

2 P. Caplan, Engendering Knowledge: The Politics of Ethnography, Part 1, „Anthropology Today” 1988, nr 5, s. 8-12.

3 J. Clifford, G.E. Marcus, Writing Culture: The Poetics and Politics of Ethnography, Berkeley 1986.

${ }^{4}$ Jedna z pierwszych tego typu konfesyjnych „opowieści z pola” autorstwa Marii Czaplickiej ukazała się już w 1916 roku. 
światy Innych. Ponadto narracja, która nie jest typowo akademickim tekstem naszpikowanym hermetyczną terminologią, pozwala dotrzeć do szerszego grona czytelników, pełni zatem lepiej funkcję popularyzującą. Warto także zauważyć, że wiele pierwszych etnograficznych autobiografii napisały kobiety, co może wynikać zarówno z ich nieustabilizowanej sytuacji w polu akademickim i braku obaw o ewentualną utratę autorytetu eksperta, jak i z konieczności poszukiwania dodatkowego zarobku (jak np. w przypadku Marii Czaplickiej)5. Obawy przed publikowaniem „nieczystych” gatunkowo tekstów są uzasadnione, jeśli rozważymy casus Paula Rabinowa i jego książkę „Refleksje na temat badań terenowych w Maroku”. Ze względu na nietypowy styl powieściowy sześć wydawnictw odmówiło jej opublikowania, a Clifford Geertz ostrzegał autora, że wydanie tej książki zrujnuje jego uniwersytecką karierę. Kobiety, jak dowodzi antropologia feministyczna, zdają się być bardziej wrażliwe w relacjach interpersonalnych, zwłaszcza w sytuacjach dominacji, a normy społeczne i kulturowe przyzwalają im na ujawnianie swoich osobistych przeżyć i emocjonalnego zaangażowania.

Etnografowie mogli także uznać, że narracyjne ramy, w jakie poukładają swoje przeżycia związane z „byciem tam” sprawią, że otworzy się przed nimi kolejna przestrzeń, poszerzające rezultaty poznawcze o istotne wymiary, uznając że pole badawcze to nie tylko otoczenie na zewnątrz badaczy, ale także oni sami, ich subiektywne przeżycia i relacje łączące ich osoby z otoczeniem poddane refleksyjnemu namysłowi. Dlatego prawdopodobnie Malinowski pisał swój Dziennik, dlatego też niektórzy antropologowie, nawet z pewnej perspektywy czasowej, sięgnęli po formę autobiograficzną, która dopełnia ich etnograficzne prace. Etnograficzną jaźń buduje się krążąc w hermeneutycznych kołach coraz szerszego oglądu siebie jako członka określonej kultury czasowo osadzonego w obcych czy odmiennych kontekstach społecznych i kulturowych. Nie jest to aż tak bardzo zaskakujące, jeśli uświadomimy sobie, że zasadniczym celem antropologii jest zrozumienie samego siebie w konfrontacji z Innymi ${ }^{6}$. Tekstualizacja osobistych doświadczeń badacza nie jest zatem aktywnością dodatkową, ale stanowi ważne ogniwo procesu badawczego, a które niezbyt często docenia się w analizach metodologicznych. Badania etnograficzne są szczególnym typem badań jakościowych, gdyż badacze nawiązują $\mathrm{w}$ procesie zbierania danych bliskie relacje społeczne badanymi, a przypisywane i osiągane statusy oraz role, także te silnie skontekstualizowane sytuacyjnie, wpływają na treść uzyskanej wiedzy etnograficznej ${ }^{7}$. Refleksja nad procesami tworzenia i negocjowania ról w badanej społeczności, które „zależą od społecznych, politycznych i kulturowych war-

${ }^{5}$ G. Kubica, Wstęp, w: Mój rok na Syberii, M. Czaplicka, Toruń 2013, s. 7-41.

${ }^{6}$ P. Collins, A. Gallinat, The Ethnographic Self as Resource: An Introduction, w: The Ethnographic Self as Resource: Writing Memory and Experience into Ethnography, red. P. Collins, A. Gallinat, Oxford 2010.

7 A. Gupta, J. Ferguson, Discipline and Practice: 'The field' as Site, Method and Location in Anthropology, w: Anthropological locations: boundaries and grounds of a field science, red. A. Gupta, J. Ferguson, Berkeley 1997, s. 15. 
tości ważnych w danym społecznym kontekście” jest kolejnym źródłem danych, które informują one bowiem badacza o strukturze lokalnego świata i relewantnych kulturowo kategoriach społecznych, wskazują one na przykład na społeczną organizację grupy (np. podziały wewnętrzne), stosunek do obcych, problemy społeczne kluczowe dla danej społeczności, a także są także konsekwencją „brzemienia białego człowieka” odpowiedzialnego za kolonialne zło9.

Błędne byłoby jednakże stwierdzenie, że to jedynie antropolog ponosi odpowiedzialność za proces badawczy. Jak słusznie zauważa Adam Kuper tubylcy nie są bierni, nie "stoją spokojnie przed kamerą", ale podejmują zróżnicowanie działania i interakcje i w ten sposób aktywnie współorganizują i przekształcają pole badawcze, pozycjonując $\mathrm{w}$ nim etnografa ${ }^{10}$. Relacje te mogą być trudne, a gotowych recept na próżno szukać wśród licznych metodologicznych książek. Dlatego też, jak sugeruje Karsten Paerregaard powinniśmy analizować teren badawczy jako „arenę intersubiektywnych interakcji, w których etnograf i jego/jej informatorzy zmagają się we wzajemnym narzucaniu sobie ról i kategorii kulturowych i ostatecznie zaprzeczają swoim tożsamościom"11.

\section{Cele badawcze i metoda badań}

Mimo coraz większego zainteresowania badawczy refleksyjnością, wiąż jeszcze - zwłaszcza na gruncie polskim - za mało uwagi poświęca się analizie tego, jak rzeczywiście przebiega proces zbierania danych w polu badawczym, który znacznie odbiega od wskazówek udzielanych przez podręczniki metodologiczne ${ }^{12}$. Etnograf, nawet jeśli ujawnia swoje doświadczenia z pola badawczego, rzadko poświęca na to całą książkę i zazwyczaj ogranicza się do informacji zawartej we wstępie, części metodologicznej lub w artykule naukowym. Są jednakże obszerne prace etnograficzne, które dają wgląd w faktycznie realizowane praktyki badawcze, są opowieściami „z pola”. Prace te nie tylko są cennym źródłem wiedzy metodologicznej dla etnografów pracujących w terenie badawczym, ale także, potraktowane jako tekst kultury, pokazują jak przez soczewkę problemy, z jakimi zmaga się współczesna antropologia: napięcie w rolach wynikające z problemu zaanga-

8 A. M. Kusow, Beyond Indigenous Authenticity: Reflections on the Insider/Outsider Debate in Immigration Research, „Symbolic Interaction” 2003, nr 26 (4), s. 592.

9 T. Asad, Anthropology and the Colonial Encounter, London 1973.

10 A. Kuper, Kultura: model antropologiczny, tłum. I. Kołbon, Kraków 2005, s. 208.

${ }^{11}$ K. Paerregaard, The Resonance Of Fieldwork. Ethnographers, Informants and The Creation of Anthropological Knowledge, „Social Anthropology” 2002, nr 10 (3), s. 331.

${ }_{12} \mathrm{Na}$ szczególną uwagę zasługują publikacje w „Przeglądzie Socjologii Jakościowej”: Anny Horolets, Badacz jako gość, 2016, nr 3, s. 54-69; Ewy Nowickiej, Antropolog wobec innych $i$ wobec siebie. Niektóre problemy etyczne uprawiania antropologii, 2016, nr 3, s. 40-53; Izabeli Ślęzak, Praca nad zaufaniem. Etyczne, praktyczne i metodologiczne wyzwania $w$ relacjach badacz-badani na przykładzie etnografii agencji towarzyskich, 2018, nr 1, s. 138-162 oraz praca zbiorowa pt. Teren w antropologii pod redakcją T. Bulińskiego i M. Kairskiego, Poznań 2011 oraz jeden z numerów Kultury i Społeczeństwa (Tom 64 Nr 2 (2020). Szerszą metodologicznie, zasługującą na szczególną uwagę jest praca Anny Wyki Badacz społeczny wobec doświadczenia (1993). 
żowania/neutralności badacza i obiektywności rezultatów poznawczych, granice działań w polu badawczym wyznaczone przez standardy etyczne.

Za Gerardem Genettem przyjmuję, że narracja to dyskurs w formie ustnej lub pisemnej, który opowiada o jakimś zdarzeniu lub serii zdarzeń rzeczywistych lub fikcyjnych. Opowiedziana może być z różnych perspektyw, w zależności od miejsca, jakie zajmuje narrator. Genett wyróżnił trzy typy fokalizacji: zerową (narrator jako wszystkowiedzący obserwator), wewnętrzną (narrator zna przeżycia i myśli bohatera/bohaterów) i zewnętrzną (narrator patrzy na bohaterów z boku, obserwuje ich działanie) ${ }^{13}$. Narracja może być prowadzona w formie pierwszoosobowej, drugoosobowej (rzadko) lub trzecioosobowej. W przypadku narracji etnograficznych, podobnie jak w przypadku autobiografii, mamy do czynienia $\mathrm{z}$ narracją $\mathrm{w}$ formie pierwszoososobowej $\mathrm{z}$ fokalizacją wewnętrzną, przeplataną narracją etnograficzną z typową dla niej fokalizacją zewnętrzną.

Barbara Tedlock zauważa, że pierwsze narracje etnograficzne zwykle były połączniem dwóch gatunków: etnograficznej monografii i autobiografii, na przykład książka Spider Woman napisana przez Gladys Reichard w 1934 roku, Santa Eulalia: The Religion of a Cuchumatan Indian Town (1947), autorstwa Oliviera La Farge, czy książka Alice Marriott pt. Greener Fields (1952). Z czasem nastąpiła wyraźna ich segmentacja. Etnografowie osobno publikowali osobiste relacje z pola badań, osobno zaś monografie (np. Colin Turnbull, John Beattie), odzwierciedlając dominujące dualizmy prywatne versus publiczne, subiektywne versus obiektywne ${ }^{14}$.

Socjologiczna (czy w tym przypadku etnograficzna) autobiografia sama w sobie jest przykładem badań, w którym autor posługuje się analitycznymi koncepcjami opowiada swoją osobistą historię w szerszym kontekście społecznym, uwzględniając relacje między podejmowanymi przez siebie działaniami a kontekstem społecznym i kulturowym ${ }^{15}$. Spojrzenie badacza skierowane jest nie tylko na to, co dzieje się wokół niego, ale także wewnątrz samego siebie, poszerzając o samym siebie zakres przedmiotu badań. Refleksyjne nastawienie polega na analizowaniu swojego miejsca w badanej społeczności, wpływu odgrywanych przez siebie ról na proces gromadzenia i uzyskane dane w kontekście biograficznych i społecznych uwarunkowań.

Refleksyjność ta jest pełna, gdy badacz prowadzi dziennik, w którym notuje swoje spostrzeżenia, jednakże zapiski te mogą ukazać się w formie uporządkowanej jako rekonstrukcja doświadczeń zdobytych podczas badań terenowych ${ }^{16}$. Zdaniem Paula Rabinowa nie można jednocześnie być w polu badawczym i przedstawić w sposób spójny

${ }^{13}$ G. Genette, Narrative Discourse. An Essay in Method, New York 1980.

${ }_{14}$ B. Tedlock, From Participant Observation to the Observation of Participation: the Emergence of Narrative Ethnography, „Journal of Anthropological Research” 1991, nr 47 (1), s. 69-94.

15 C. A. Davies, Reflexive Ethnography. A Guide to Researching Selves and Others, London and New York 1999.

${ }^{6}$ P. Nilan, 'Dangerous Fieldwork' Re-Examined: The Question Of Researcher Subject Position, „Qualitative Research” 2000, nr 3, s. 363-386. 
swoich doświadczeń z pola badań, gdyż to, co pojawia się jako zdarzenie później rzuca światło na zdarzenia wcześniejsze i ramuje ich interpretację ${ }^{17}$. Dlatego też refleksyjna analiza może być domknięta dopiero wtedy, gdy badacz spogląda na zdarzenia z pola badań z pewnego dystansu. Etnograficzna jaźń budowana jest z jednej strony w procesie interakcji badacza $z$ innymi ludźmi, a następnie rekonstruowana podczas tworzenia narracji. Ten gatunek narracji nazywany jest niekiedy opowieścią konfesyjną lub tekstem nieoficjalnym ${ }^{18} \mathrm{Czy}$ „antropologiczną powieścią”, która portretuje „wewnętrzne doświadczenia pola badawczego"19, ale także opowiada o badanej społeczności uwzględniając swój wpływ na przebieg zdarzeń. Dzięki temu czytelnik nie tylko dowiaduje się o doświadczeniach badanych ludzi, ale także o tym, jak osoba badacza wpływała na te doświadczenia i jak inni kształtowali jego sposób przekazywania świata ${ }^{20}$.

$\mathrm{W}$ artykule chciałabym poddać analizie siedem narracji etnograficznych z pola badań. Powstawały w różnym czasie, są wspomnieniami pobytu wśród zróżnicowanych kulturowo ludów, w których badacz żył minimum jeden rok (zob. tabela 1) ${ }^{21}$. Wszystkie te prace cechuje głęboka refleksywność, nie w sensie radyklanej refleksywności jako narzędzia transformacji społecznej, lecz rozumiana jako namysł nad społecznymi uwarunkowaniami wiedzy ${ }^{22}$. Prowadząc analizę wybranych tekstów nie korzystałam z metod typowych dla analizy narracji, które skupiają się głównie na morfologii tekstu: jego strukturze, sekwencyjności zdarzeń, linii wątków, binarnych opozycjach i charakterystykach postaci/aktorów, poziomach narracji ${ }^{23}$. Oczywiście wybrane teksty można badać za pomocą zaproponowanych przez narratologię narzędzi analitycznych. Mnie natomiast interesuje nie tle warstwa tekstualna narracji, ale jej zawartość treściowa, choć zdaję sobie sprawę, że nie da się ich od siebie oddzielić. Jest to raczej kwestia wyboru, która $\mathrm{z}$ warstw będzie pierwszoplanowa. W przypadku tego gatunku narracji, jakim jest autobiografia,

17 P. Rabinow, Refleksje na temat badań terenowych w Maroku, tłum. K.J. Dudek i S. Sikora, Kęty 2010, s. $34-35$.

${ }_{18}$ J. van Maanen, Tales of the Field: On Writing Ethnography, Chicago 1988; D. Ceglowski, Research as Relationship, „, Qualitative Inquiry” 2000, nr 6(1), s. 88-103.

19 L. Bohannan [pseud. Bowden E. S.], Return to Laughter, New York 1954, s. XVI.

20 D. Mahoney, Constructing Reflexive Fieldwork Relationships: Narrating My Collaborative Storytelling Methodology, „Qualitative Inquiry” 2007, nr 13 (4), s. 573-94.

${ }^{21}$ Zdaję sobie sprawę, że prac autoetnograficznych jest znacznie więcej. Niektóre powstały przezd II wojną światową, na przykład wzmiankowana praca Gladys Reichard pt. Spider Woman czy Santa Eulalia (1947), autorstwa Oliviera La Farge, inne zaś w latach 50. XX wieku (np. Alice Marriott, Greener Fields, 1952; Robert Lowie, Etnologist: A personal Record, 1959). Najwięcej jednak narracji etnograficznych pojawiło się po 1960 roku. Barbara Tedlok (1991) w swoim o znakomitym artykule na temat pierwooszobowych narracji etnograficznych wymienia niemal 90 publikacji anglojęzycznych, które ukazały się do końca lat 90 . Ze zwzględu zatem na tak dużą liczbę tekstów z konieczności musiałam dokonać selekcji tekstów, starając się, aby reprezentowały one różne przedziały czasowe.

${ }^{22}$ E. Hałas, Refleksyjność jako zasada i problem teorii społecznej, „Zagadnienia Naukoznawstwa” 2011, nr 2 (188), s. 191-202.

${ }^{23}$ np. M. Bal, Narratology. Introduction to the Theory of Narrative, Toronto 1985 ; B. Thomas, Narrative. The Basics, London, New York 2016. 
można skupić się na tych aspektach, które wykorzystywane są w analizie wywiadu narracyjnego. Wykorzystując wyróżnione przez Fritza Schützego struktury procesowe, interesowały mnie wzorce instytucjonalne, które narzucają badaczom pewne role i powiązane z nimi oczekiwania, które mogą zderzać się z biograficznymi schematami działania, czyli projektami, które jednostka chce zrealizować. Jako obcy w terenie badawczym badacze tracą częściowo, a nawet czasem całkowicie, kontrolę nad swoją sytuacją życiową i muszą poddać się sytuacji wrzucenia w trajektorię. Z czasem wypracowują nowe schematy działania, często okupione cierpieniem, albo przeżywają biograficzne metamorfozy, które radykalnie zmieniają ich dotychczasowy sposób życia ${ }^{24}$.

Tabela 1. Charakterystyka analizowanych źródeł

\begin{tabular}{|c|c|c|c|}
\hline Autor & Tytuł & Rok wydania & Pole badań i okres pobytu \\
\hline $\begin{array}{l}\text { Maria Czaplicka } \\
(1886-1921)\end{array}$ & Mój rok na Syberii & $\begin{array}{l}1916 \text {, wyd. pol. } \\
2013\end{array}$ & $\begin{array}{l}\text { Badania wierzeń szamańskich ludów północnej } \\
\text { Syberii, Nieńców i Dołganów, prowadzone w la- } \\
\text { tach 1914-1915, włączając w to mroźne miesiące } \\
\text { zimowe. }\end{array}$ \\
\hline $\begin{array}{l}\text { Laura Bohannan } \\
(1922-2002), \\
\text { pseud. Eleonore } \\
\text { Smith Bowen }\end{array}$ & Return to Laughter & 1954 & $\begin{array}{l}\text { Jedne z nigeryjskich plemion, prawdopodobnie } \\
\text { Tiwowie, choć autorka nie wymienia nazwy tego } \\
\text { ludu, w trosce o jego anonimowośc. Badania pro- } \\
\text { wadzone w latach 1949-53. }\end{array}$ \\
\hline $\begin{array}{l}\text { Horense } \\
\text { Powdermaker } \\
(1900-1970)\end{array}$ & $\begin{array}{l}\text { Stranger and } \\
\text { Friend. The Way of } \\
\text { an Anthropologist }\end{array}$ & 1966 & $\begin{array}{l}\text { Czterech różne pola badawcze: 1. lud Lesu za- } \\
\text { mieszkujący Nową Irlandię, małą wyspę w No- } \\
\text { wej Gwinei (badania w latach 1929-30), 2. wiej- } \\
\text { skie społeczności nad Missisippi ( lata 1933-34), } \\
\text { 3. środowisko filmowców Hollywood (lata 1946- } \\
\text {-47) 4. afrykańskie miasteczka górnicze w Pół- } \\
\text { nocnej Rodezji (Zambia) (1953-54). }\end{array}$ \\
\hline $\begin{array}{l}\text { Jean L. Briggs } \\
(1929-2016)\end{array}$ & $\begin{array}{l}\text { Portrait of an } \\
\text { Eskimo Family }\end{array}$ & 1970 & $\begin{array}{l}\text { Badanie przez } 18 \text { miesięcy (czerwiec 1963-ma- } \\
\text { rzec 1965) życia rodzinnego ludu Utku (Utkuhi- } \\
\text { khalingmuit), nomadycznych Eskimosów żyją- } \\
\text { cych nad Zatoką Hudsona }\end{array}$ \\
\hline $\begin{array}{l}\text { Paul Rabinow } \\
\text { (ur. 1944) }\end{array}$ & $\begin{array}{l}\text { Refleksje na temat } \\
\text { badań terenowych } \\
\text { w Maroku }\end{array}$ & $\begin{array}{l}\text { 1974, wyd. pol. } \\
2010\end{array}$ & $\begin{array}{l}\text { Wspomnienia z pobytu Rabinowa wśród maro- } \\
\text { kańskich chłopów (1968-69). }\end{array}$ \\
\hline $\begin{array}{l}\text { Nigel Barley } \\
\text { (ur. 1947) }\end{array}$ & $\begin{array}{l}\text { Niewinny antro- } \\
\text { polog }\end{array}$ & $\begin{array}{l}\text { 1983, wyd. pol. } \\
1997\end{array}$ & $\begin{array}{l}\text { Badania prowadzone przez dwa lata w Kamerunie } \\
\text { u Dowayów. }\end{array}$ \\
\hline $\begin{array}{l}\text { Paul Stoller } \\
\text { (ur. 1947), Cheryl } \\
\text { Olkes (1956-1998) }\end{array}$ & $\begin{array}{l}\text { In Sorcery's } \\
\text { Shadow, A mem- } \\
\text { oire of Apprentice- } \\
\text { ship among the } \\
\text { Songhay of Niger }\end{array}$ & 1987 & $\begin{array}{l}\text { Autorzy opisują historię wtajemniczenia i prakty- } \\
\text { kowania przez Stollera magii sorko. Wspomnie- } \\
\text { nia obejmują jego wielokrotne pobyty w wio- } \\
\text { skach ludu Songhay w Nigerii w latach } 1976-84 \text {. }\end{array}$ \\
\hline
\end{tabular}

Źródło: opracowanie własne

We wszystkich przypadkach, za wyjątkiem Marii Czaplickiej i częściowo Paula Stollera, etnografowie prowadzili badania jednoosobowo. Analizowane autobiografie two-

${ }^{24}$ zob. K. Kaźmierska, Wywiad narracyjny - technika i pojęcia analityczne, w: Biografia i wojna. Metoda biograficzna w badaniu procesów społecznych, R. Dopierała i K. Waniek (red.), Łódź 2016, s.61-72. 
rzone są już po opuszczeniu przez badaczy pola badań. Głos badacza w omawianych publikacjach wybrzmiewa w rożną siłą. We wspomnieniach Czaplickiej pojawia się intensywnie w pierwszej części książki, w drugiej zaś usuwa się w cień, a narracja przekształca się w etnograficzny tekst o kulturze ludów syberyjskich. W innych zaś narracjach osoba badacza stale jest obecna (np. Barley, Powdermaker) lub staje się centralnym aktorem dopiero w ostatniej części książki (np. Briggs).

Narracja prowadzona jest w porządku chronologicznym, tworząc łańcuch zdarzeń: przybycie, pierwszy kontakt, oswojenie terenu, wyjazd. Często opis pierwszego ogniwa łańcucha jest mocno udramatyzowany, przypominające heroiczne powieści kolonialne ${ }^{25}$. Etnografowie opisują liczne przeszkody, które utrudniały im dotarcie na miejsce, takie jak uciążliwości biurokratyczne, długa podróż rozklekotanym samochodem dziurawymi lub błotnistymi drogami. Także praca w trenie badań najeżona była licznymi uciążliwościami, i tak jak bohaterowie bajek, który podczas swoich wpraw musza się zmagać z licznymi przeciwnościami, aby ostatecznie odnieść zwycięstwo ${ }^{26}$, tak też etnografowie opisują nękające liczne przeszkody, takie jak niestrawność (Barley, Stoller), żółtaczka (Barley), przeziębienie i depresja (Briggs), syberyjskie 50-stopniowe mrozy, purga, głód (Czaplicka, Briggs), upał (Powdermaker, Bohannan), fatalne jedzenie (Briggs, Barley, Powdermaker), termity pożerające notatki, skorpiony w butach, cuchnące kozy włażące do sypialni (Barley) oraz ogromne zmęczenie (Barley, Czaplicka, Briggs). Barley tak opowiada o dniu, w którym poziom wyczerpania przekroczył granice wytrzymałości: „Siadłem na pobliskim kamieniu, nie mogąc w ogóle poruszać nogami. Zaczęło strasznie lać, ale jakikolwiek ruch był nadal poza zakresem moich możliwości. Przypomniałem sobie, że jest to dzień moich urodzin, i najzwyczajniej się rozpłakałem"27.

Analizowane teksty nie są czystym gatunkiem opowieści według typologii Johna van Maanena, który wyróżnił trzy typy narracji: realistyczną, konfesyjną i impresjonistycz$n a ̨{ }^{28}$. Niektóre fragmenty mają cechy narracji realistycznych, w których autorzy dążą do przedstawienia faktów, cytują wypowiedzi badanych, opisują ich poglądy i zachowania. Jednakże dominuje osobiste sprawozdanie, w którym wyrażone są przeżycia i poglądy autora czy autorki charakterystyczne dla opowieści konfesyjnej, można także zauważyć cechy opowieści impresjonistycznych, których główną funkcją jest wywarcie na czytelniku wrażenia, że badacza był faktycznie „tam” i angażował się w życie społeczności. W tekstach pojawiają się formy dialogiczne, a także szczegółowe opisy zdarzeń. Narracja Barley’a i Czaplickiej jest bliższa opowieści realistycznej, natomiast tekst Stollera, w dużej części udialogizowany dzięki nagraniom magnetofonowym oraz skrupulatnym notatkom, zbliża się typologicznie do typu konfesyjnego, praca Briggs w pierwszej części jest narracja realistyczną, w drugiej zaś konfesyjną. W tekstach autorstwa Rabinowa, Bo-

\footnotetext{
25 A. Gupta, J. Ferguson, Discipline and Practice: 'The field' as Site...s. 101-146.

26 W. Propp, Morfologia bajki, „Pamiętnik Literacki” 1968, nr 59/4, s. 203-242.

27 N. Barley, Niewinny antropolog, s. 129.

${ }^{28}$ J. van Maanen, Tales of the Field: On Writing Ethnography, Chicago 1988.
} 
hannan i Powdermaker przeważa typ konfesyjny, przemieszany $z$ fragmentami narracji realistycznej.

\section{Wzorce instytucjonalne}

Przybywający do wioski antropolodzy stykali się już od pierwszej chwili z podzielany$\mathrm{mi} \mathrm{w}$ danej społeczności wzorcami instytucjonalnymi. Pierwszy kontakt $\mathrm{z}$ badaczem zawsze budził ogromne zainteresowanie członków społeczności lokalnej, którzy gromadzili się licznie, aby obserwować niezwykłego przybysza. W początkowej fazie role obserwatora odwróciły się: to etnografowie byli poddani nieustannej obserwacji, zaglądano przez szpary do ich mieszkania, podglądano w czasie kąpieli, gromadzono się przed jego chata i śledzono ich ruchy. Inną strategią oswajania się z obcymi przybyszami jest włącznie ich w system istniejących w kulturze lokalnej typizacji. Gdy mieszkańcy wiosek mieli bardzo nikłe pojęcie na temat zróżnicowania kulturowego świata cywilizacji europejskiej, sposoby kategoryzowania antropologów były bardzo ogólne i badacze byli po prostu traktowani jako przedstawiciele świata Białych lub przedstawicieli narodu, z którym tubylcy mieli kontakt. Na przykład ludy syberyjskie traktowały Czaplicką jako Rosjankę, bo tak postrzegali wszystkich Europejczyków, Stoller z kolei był nazywany przez pewien czas Anasara (Europejczyk), choć faktycznie był Amerykaninem. Barley i Rabinow brani byli za misjonarzy, a także budzących powszechną podejrzliwość urzędników, wśród władz zaś za szpiegów lub przemytników, natomiast Powdermaker za dziennikarkę, która opisze w niekorzystnym świetle istniejące stosunki społeczne w małych miasteczkach stanu Missisipi. Na te ogólne typifikacje nakładano zróżnicowaną siatkę ról narzucanych badaczom. Antropologowie bardzo szybko osadzeni zostali przez społeczność w roli lekarzy, do których codziennie rano ustawiały się kolejki ludzi z różnymi przypadłościami (Barley, Czaplicka, Bohannan, Powdermaker). Jeśli badacze mieli samochód, stawali się kierowcami darmowej taksówki „dla ludzi z małymi pieniędzmi i wielkimi oczekiwaniami”29, co bywało tak uciążliwe, że Rabinow postanowił pozbyć się pojazdu, aby uniknąć próśb o podwiezienie nękających go świtu do nocy. W przypadku kobiet bardzo ważny okazał się stan cywilny. Z góry zakładano, że badaczki są w zawiązku małżeńskim i były często wypytywane o męża i dzieci. Dlatego też, aby uniknąć zawiłych tłumaczeń antropolożki przedstawiały się rozwódki, które rozstały się z mężem z powodu jego kiepskiej pracy, co znajdowało zrozumienie wśród innych kobiet (Powdermaker), ewentualnie unikały odpowiedzi, zmieniając temat rozmowy (Czaplicka). Etnografowie traktowani byli jako przedstawiciele „bogatych białych ludzi” z rolami obciążonymi stosunkami kolonialnymi. Na przykład nie pozwalano im wykonywać żadnych prac fizycznych, które nie pasowały do statusu Białych (np. sprzątanie, praca w ogrodzie), delegując do nich wyznaczonych mieszkańców, który czerpali z tego

${ }^{29}$ N. Barley, Niewinny antropolog, s. 63. 
tytułu korzyści materialne wymuszając na badaczach wysokie opłaty uszczuplające budżet badawczy.

Doświadczenia badaczy wskazują, że relacje dominacji w interakcjach nie są z góry ustalone, a władza nie jest automatycznie przypisywana jest etnografom przybywającym z dominujących technicznie krajów lecz podlega negocjacji, formułowane są wobec niego określone kulturowo oczekiwania ${ }^{30}$. Antropolog jest w terenie badawczym gościem, który musi przestrzegać zwyczajowych reguł gościnności, gdyż „status gościa jest delikatny i zależy od właściwego zachowania wobec gospodarza" ${ }^{\text {"1 }}$. W wielu sytuacjach członkowie społeczności badanej decydowali z kim, w jakich okolicznościach i na jakich zasadach etnografowie będą mogli prowadzić prace badawcze. Jak słusznie zauważa Scott Grills niektóre role są podejmowane z własnej woli badaczy, inne zaś im narzucane przez uczestników badanego życia społecznego ${ }^{32}$. Przykładem może być Jeane Briggs, która po przybyciu do wioski, została adoptowana przez rodzinę Eskimosów jako córka. Rodzina, z którą miała wspólnie żyć została jej przydzielona bez jej zgody, narzucono jej towarzystwo osób, z którymi musiała mieszkać w jednym, ciasnym iglo. Z kolei Bohannan została przez lokalną społeczność uznana za matkę swoich służących i w związku z narzucono jej związane z tą rolą obowiązki: karmienia swoich „dzieci”, ochronę i zaspakajanie ich potrzeb. Płeć badacza mogła, ale nie musiała ograniczać dostępu do danych. Barley mógł bez problemów prowadzić rozmowy z kobietami bez obecności innych mężczyzn, gdyż uznano go za bezpłodnego, a zatem zupełnie niegroźnego z punktu widzenia relacji płciowych. Czaplicka zaś wspomina, że jej status obcej kobiety pozwolił jej na uczestnictwo w męskich wiecach, na które kobiety nie miały prawa przychodzić.

Brak kompetencji kulturowych, a także często także językowych, sprawia, że etnograf przyjmuje rolę ucznia poddanego socjalizacji. Tubylcy nie zauważali kompetencji badaczy, degradowali ich ze statusu eksperta, niekiedy niepochlebnie wypowiadali się o ich potencjale umysłowym. Na przykład Czaplicka usłyszała kiedyś taki komentarz dotyczący swojej osoby: „Myślę, że nie jest zbyt bystra, chociaż ma ze sobą sporo papieru”33. Członkowie społeczności podejmowali próby „wychowywania” etnografów. O Powdermaker, która miała status adoptowanej córki, jeden z mieszkańców wioski mówił: „Wiesz, kiedy przyjechała tutaj była głucha. Nie potrafiła mówić. Była jak dziecko. Nic nie wiedziała. Ale teraz wszystko się zmieniło. Mówi i rozumie nas, zna naszą magię, umie tańczyć z kobietami (...) Kto jest za to odpowiedzialny? Ja"34. Podobne wspomina swoją sytuację Bohannan, która łajana była na przykład za brak manier, zły styl ubierania

${ }^{30}$ S. B. Merriam, J. Johnson-Bailey, L. Ming-Yeh, Power and Positionality: Negotiating Insider/Outsider Status within and across Cultures, „International Journal of Lifelong Education” 2010, nr 20 (5), s. 405-416.

31 E. Murphy, R. Dingwall, Informed Consent, Anticipatory Regulation and Ethnographic Practice, „Social Science \& Medicine" 2007, nr 65, s. 2225.

${ }^{32}$ S. Grills, An Invitation to the Field: Fieldwork and the Pragmatists' Lesson, w: Doing Ethnographic Research, red. S. Grills, Thousand Oaks 1998, s. 3-20.

${ }^{33}$ M. Czaplicka, Mój rok na Syberii, s. 86.

${ }^{34}$ H. Powdermaker, Stranger and Friend. The Way of an Anthropologist, New York 1966, s. 120. 
się, chodzenie w mokrych butach: „Czułam się bardziej uwstecznionym, upośledzonym dzieckiem niż niezależną, młodą kobieta" ${ }^{35}$. Briggs poprzez adopcje została zdegradowana do statusu trzyletniego dziecka, o którego stale trzeba było się troszczyć. Nie potrafiła dać sobie rady z prostymi czynnościami życiowymi, takimi jak przygotowanie posiłku, zapewnienie sobie ciepła, naprawa podartej odzieży. Dla dojrzałej kobiety, przywykłej do samodzielności, była to sytuacja niezwykle stresująca. Była stale krytykowana za złe zachowanie i pouczana. $Z$ czasem jej sytuacja stała się na tyle trudna, a jej depresyjne nastroje, przeplatane wybuchami irytacji, nieakceptowane w kulturze Eskimosów, że została ona skazana na izolację i ostracyzm. W tych warunkach trudno było dalej prowadzić badania terenowe i Briggs powróciła do domu.

Badacz często skazany jest, przynajmniej w początkowej fazie badań, na tłumaczy, dlatego też są oni jedną z kluczowych postaci w polu badawczym, które narzucają określone schematy działania i kierunek procesu badawczego. Ich rola nie ogranicza się jedynie do przekładu komunikatów językowych, często są także nauczycielami języka tubylczego, głównymi informatorami wprowadzającymi badaczy w zawiłości kultury lokalnej. Pomagają oni zawierać przydatne dla antropologów znajomości, jest także są przewodnikami oprowadzającym po miejscach ważnych ${ }^{36}$. Mogą być jednakże osobami znacznie utrudniającymi zbieranie danych, sprawującymi kontrolę nad badaczem. Dlatego też Stoller, który nie korzystał z tłumaczy, gdyż w czasie swoich wcześniejszych pobytów w Afryce nauczył się języka Songhajów w stopniu komunikatywnym, uważał, że rola tłumacza jest jak kamizelka ratunkowa, która daje poczucie bezpieczeństwa, ale nie pozwala się zanurzyć w badanej kulturze, aby uzyskać zadowalający poziom wglądu. Czaplicka żaliła się, że jej tłumaczka celowo tłumaczyła źle, gdy miała zły humor lub uznała, że otrzymuje od etnografki za mało wartościowe podarki. Pewnego dnia wyjawiła jej także, co wzbudziło dużą nieufność badaczki, że gdyby Czaplicka zmarła, to odziedziczyłaby po niej wszystkie posiadane rzeczy. Rabinow z kolei narzekał, że jego relacje z tłumaczami często oparte były na dominacji, narzucaniu etnografowi roli gościa, który musie się podporządkować inicjatywom gospodarza i okazywać za nie wdzięczność.

Ważnym źródłem informacji była służba domowa, odpowiedzialna za utrzymanie czystości w domostwie i przygotowanie posiłków. Zwykle były to jedna, a czasami dwie osoby, bez których badacz musiałby poświęcić ogromną ilość czasu na prace domowe. Relacje z nimi przekraczały granice stosunków formalnych i przybierały formę patronatu: „człowiek, który dla ciebie pracuje, nie jest jedynie twoim pracownikiem - raczej ty jesteś jego dobrodziejem. I jest to związek oparty na bardzo niejasnych warunkach”37. Antropolodzy szybko wikłali się w system powinności. Żądano od badaczy pomocy materialnej, bezzwrotnych pożyczek dla siebie i rodziny (Barley), fundowania rodzinnych

${ }^{35}$ L. Bohannan, Return to Laughter, New York 1954, s. 37.

${ }^{36}$ S. Grills, An Invitation to the Field: Fieldwork and the Pragmatists' Lesson, w: Doing Ethnographic Research, red. S. Grills, Thousand Oaks 1998, s. 3-20.

37 N. Barley, Niewinny antropolog, s. 45 
uroczystości (Bohannan), finasowania podróży (Stoller, Rabinow). Kontakty w badaczem miały przynosić materialny zysk, a antropolog „W najlepszym razie mógł liczyć na to, że będzie traktowany jako nieszkodliwy idiota, którego obecność przynosi wiosce określone korzyści”38. Nawet niektórzy nauczyciele przekazujący Stollerowi wiedzę magiczną nie robili tego bezinteresownie. Etnograf zdawał sobie sprawę, że jest przedmiotem manipulacji, której celem było wyłudzenie pieniędzy lub otrzymanie cennych podarków przywiezionych przez etnografa z USA i do pewnego stopnia zgadzał się na to. Jednakże Stoller, podobnie jak Rabinow przez długi czas łudzili się, że ich bliskie relacje z niektórymi tubylcami są bezinteresowne i przezywali rozczarowanie, a nawet przygnębienie, gdy okazało się, że to jedynie sprawa interesów ukryta pod pozorem przyjaźni.

Reasumując, doświadczenia badaczy wskazują, że błędne jest przeświadczenie, o tym, że tubylcy jedynie „dają” informacje, a badacz jest wyłącznie biorcą. Okazuje się, że społeczności lokalne bardzo szybko włączały etnografów we obieg świadczenia sobie wzajemnych usług. Co więcej, niektóre osoby, z którymi współpraca była bardziej intensywna (kucharze, tłumacze) próbowali zbudować „posesywny typ relacji”, polegający na traktowaniu etnografa jak swoją własność, roszczeniu sobie do niego praw opartych na wyłączności oraz angażowaniu się w relacje w taki sposób, aby jak najbardziej uzależnić badacza od oferowanych przez siebie usług. Etnografowie zwykle z lęku i obawy przez ostracyzmem, akceptowali, przynajmniej pozornie, narzucane im wzory postepowań, ale zdarzało się także, że podejmowali zakończone sukcesem negocjacje.

\section{Biograficzne schematy działania}

Zastane wzorce instytucjonalne wpływają na zachowania i role badaczy, ale zwykle nie uniemożliwiają badaczom realizację własnych biograficznych schematów działania. Aby osiągnąć cele badawcze antropolodzy muszą zadbać o zbudowanie relacji w polu badawczym. Relacje te mogą mieć zróżnicowany charakter (np. przyjacielskie, bliskie, koleżeńskie, dominujące) i zmieniać się w czasie. Można wyróżnić kilka faz tworzenia relacji: od formalnej, zdepersonalizowanej do zintensyfikowanej i zaangażowanej emocjonalnie, w której role badanego i badanego tracą swoje pierwotne znaczenie (choć nie wszystkie relacje muszą jednak przechodzić przez wszystkie fazy). Etnograf musi podjąć takie działania, które pozwolą mu przełamać bariery wynikające z obcości. W badanych narracjach kluczową rolę w przełamywaniu obcości i negocjowaniu ról miało doskonalenie przez badaczy kompetencji językowych, umożliwiających swobodną wymianę zdań bez pośrednictwa tłumacza. Z czasem badani oswoili się z obcością badaczy, zaakceptowali ich obecność, a nawet w pewnym stopniu włączyli ich do społeczności, co często przejawiało się w zmianie sposobu nazywania antropologów. Na przykład Barley zauważa,

38 N. Barley, Niewinny antropolog, s. 62. 
że mówili o nim „nasz biały”39. Bohannan początkowo była „białą kobietą”, gdy już nawiązała bardziej zażyłe relacje była nazywana „naszą Europejką”, a potem „przyjaciółką” samego wodza wioski ${ }^{40}$.

Pozycja badaczy nie zależała jedynak jedynie od kompetencji kulturowych i komunikacyjnych, choć były one ważnym narzędziem w negocjacjach ról. Antropolog mógł podwyższyć swój status w społeczności posiadaniem interesujących sprzętów lub wykazywaniem pewnych umiejętności. Na przykład Barley imponował Dowayom, tym że nie okazywał lęku przed kameleonami i sowami, posiadał materac i magnetofon. Bohannan nie bała się piorunów kulistych i sów, które według wierzeń towarzyszyły złym czarownicom, więc mieszkańcy wioski szukali u niej ochrony w czasie burzy lub zlotu tych nocnych ptaków.

Istniejące w społeczności napięcia i antagonizmy były nie tylko przedmiotem badań, ale mogły być także wykorzystywane jako metoda pozyskiwania danych i ułatwiały realizację własnych schematów biograficznych. Barley na przykład wzniecał rywalizację między zaklinaczami deszczu, aby uzyskać od nich jak najwięcej informacji na temat tego rytuału. Rabinow wykorzystał sytuację skłóconych miedzy sobą miejscowych lineaży, które początkowo nie chciały z nim współpracować. Jednakże z obawy, że nielubiany przez mieszkańców wioski tłumacz-informator będzie jedynym źródłem danych etnografa, przełamano zmowę milczenia, aby uzyskać jak największą kontrolę nad płynącymi do antropologa informacjami. Sprytna gra badacza manewrującego między skłóconymi stronami otworzyła mu dostęp do zróżnicowanych danych. Powdermaker wspomina, że była na tyle silnie utkana w siatkę antagonizmów na tle rasowym dominujących w społecznościach małych miast na południu USA, że musiała prowadzić dyplomatyczna grę, w której nie mogła zdradzić się ze swoimi sympatiami w stosunku do Afroamerykanów, aby nie być napiętnowaną przez Białych, z drugiej zaś strony nie zaprzyjaźniać się z nimi, aby nie wzbudzić podejrzeń Afroamerykanów, którzy po pewnym czasie uznali ją za członka swojej grupy etnicznej, co znacznie ułatwiło jej prace badawczą. Jednakże ten społeczny rozłam rzutował na wewnętrzne dylematy tożsamościowe, na tyle głębokie, że Powdermaker zaczęła wątpić w swoją przynależność do białej rasy i sprawdzała przed lustrem, czy jej skóra nie stała się ciemna.

Warto także sygnalizować, że przy realizacji własnych schematów biograficznych badacze napotykali pewne metodologiczne rozterki. Celem działań badawczych etnografów jest poznanie obcej kultury poprzez nawiązywanie bezpośrednich kontaktów w polu badawczym. Trudno jest jednoznacznie stwierdzić, że bliskie relacje z badacza z badanymi są owocne dla badań, gdyż zdania metodologów są w tej sprawie podzielo$\mathrm{ne}^{41}$. Gdy badacz staje się całkowitym uczestnikiem badanego życia społecznego, przez

39 N. Barley, Niewinny antropolog, s. 62.

40 L. Bohannan, Return to Laughter, New York 1954, s. 74.

${ }^{41}$ Więcej na ten temat w artykule: J. Bielecka-Prus, Między obcościa a swojskością. Negocjowanie roli etnografa $w$ terenie badawczym, w: Człowiek $w$ kulturze. Kultura w człowieku, red. U. Kusio, K. Szcześniak Lublin 2018, s. 25-46. 
swoje zaangażowanie nie tylko otwiera sobie szerzej dostęp do danych, ale sam jest ich twórcą ${ }^{42}$. Bardzo łatwo wtedy o „stubylczenie”, przed którym przestrzegali etnografowie ze Szkoły Chicagowskiej, bowiem w roli tej traci się umiejętność zobiektywizowanego i analitycznego spojrzenia na zachodzące wokół procesy. Zupełnie inne stanowisko zajmują etnometodolodzy i badacze preferujący socjologię egzystencjalną. Uważają oni bowiem, że doświadczenia osobiste są niezwykle cennym źródłem danych, a nawiązywanie bliskich relacji z badanymi warunkiem uzyskania od nich wiarygodnych informacji, wejścia w społeczne światy badanych i ich zrozumienie niejako „od wewnątrz”.

A zatem każdy badacz musiał podjąć decyzję dotyczącą tego, na ile głęboko chce zanurzyć się w badana kulturę i poddać się wtórnej socjalizacji: przyswoić schematy myślenia, podporządkować swoje działania instytucjonalnym wzorom. W analizowanych narracjach etnograficznych możemy znaleźć dwa typy schematów biograficznych. Pierwszy, skrajny, reprezentowany jest przez Stollera, który poddał się socjalizacji i stał się jednym z czarowników praktykujących magię sorko. Większość jednak badaczy nie zaangażowała się aż tak głęboko i totalnie. Na przykład Powdermaker zauważyła, że mimo emocjonalnego zaangażowania nigdy nie przestała być antropologiem i zdawała sobie sprawę, że „nieważne jak intymne były i przyjacielskie były jej relacje z tubylcami nigdy nie była naprawdę częścią ich życia”ł3. Nie wykluczało to jednak możliwości wzajemnego zrozumienia budowanego na przekonaniu o jedności wszystkich istot ludzkich. Podobne stanowisko zajęła Bohannan, która „lubiła, być między nimi, tak jak lubiła zanurzyć się w morzy, ale żadna z tych sytuacji nie stała się jej naturalnym środowiskiem” ${ }^{\text {" }}$.

\section{Punkty zwrotne i epifanie}

W opowieściach etnografów można zauważyć, że pojawia się jakiś jeden lub kilka punktów zwrotnych które radykalnie zmieniły relacje z badanymi lub/i koncepcję badań. Punkty te mogą być dziełem szczęśliwego lub niefortunnego zbiegu okoliczności, ale mogą także wynikać z działań samego badacza i społeczności. Barley przyznaje, że ważne było wspólne palenie tytoniu i picie niesmacznego piwa z prosa, jednakże wyraźna zmiana nastąpiła wtedy, gdy zdecydował się na kąpiel nago w rzece, podczas której mężczyźni z wioski najpierw omówili szczegóły jego budowy anatomicznej, a następnie wtajemniczyli go w strukturę wierzeń religijnych. Jego pozycja wzrosła także, gdy badacz utracił część swoich zębów i zmuszony był używać sztucznych, które wypadały mu czasem w trakcie mówienia. Powdermaker wspomina, że ważnym zwrotem było jej uczestnictwo w rytualnym tańcu, w którym „zapomniała o sobie i była jedną z tancerek. W czasie tej pełni księżyca, na krótki czas przestała być antropologiem z nowoczesnego społeczeństwa. Tańczyła” ${ }^{35}$. Po

\footnotetext{
${ }^{42}$ P.A. Adler, P. Adler, Membership Roles in Feld Research, Newbury Park 1987.

${ }^{43}$ H. Powdermaker, Stranger and..., s. 116.

${ }^{44}$ L. Bohannan L. [pseud. Bowden E. S.], Return to Laughter, New York 1954, s. 26.

45 tamże, s. 112.
} 
tym zdarzeniu mieszkańcy stali się wobec niej bardziej otwarci i swobodni, chętnie podejmowali z nią kontakty. Dla Stollera przełomem w badaniach było małe lanie spuszczone przez badacza jednemu z niegrzecznych dzieci, które od początku pobytu dręczyły go, rzucały w niego kamieniami, wchodziły do łóżka i ciągnęły za włosy. Dorośli dopiero wtedy uznali go za osobę i pozwolili mu notować przebieg rozmów. Innym kluczowym punktem zwrotnym, który ostatecznie doprowadził do epifanii Stollera była defekacja. Otóż jeden z ptaków latających po chacie badacza wydalił nieczystości na jego głowę. Całe zdarzenie obserwował miejscowy czarownik, dla którego był to wystarczający dowód na to, że antropolog jest świetnym materiałem na ucznia magii.

Nie tylko jednak zwroty, które skutkowały większą zażyłością z tubylcami, są ważne dla badań, ale także takie sytuacje, w których następuje załamanie komunikacji, zerwanie relacji, a następnie poszukiwanie porozumienia. Uświadamiają one etnografom różnice kulturowe, jakie zachodzą między nimi a badanymi, ale także tworzą drogi wzajemnego zrozumienia, „przedzierania się w nowe rejony”, które otwierają nowe kody interpretacyjne ${ }^{46}$. Tak na przykład było, gdy Powdermaker poradziła rodzinie ciężko chorej na epidemię dziewczynki, aby zabrać ją do szpitala. Mieszkańcy uznali, że chce skrzywdzić dziecko, gdyż w szpitalu ludzi spotyka śmierć i badaczka musiała włożyć dużo trudu, aby przekonać mieszkańców, że nie miała złych intencji. Bohannan zrozumiała wtedy wyraźnie, że różnice w sposobach interpretowania zdarzeń, jakie dzielą ją od mieszkańców wioski są bardzo głębokie i nie do pokonania, gdy oskarżono jej o to, że nie chce uleczyć choroby dziecka, mimo iż próbowała wyjaśnić, że nie potrafi tego zrobić. Gdy zmarła inna mieszkanka wioski i jeden z mężczyzn został oskarżony o czary, które spowodowały tę śmierć, etnolożka stanęła w jego obronie, co skutkowało tym, że razem z nim skazana została na ostracyzm, „stała się niewidzialna”: nie witano się z nią, nie odpowiadano na jej pytania ${ }^{47}$. Musiała zerwać $\mathrm{z}$ nim kontakt, aby odzyskać sympatię mieszkańców wioski, co wywołało u niej poczucie winy. Jej sytuacja uległa pogorszeniu, gdy do wioski dotarła epidemia czarnej ospy. Zdrowi mieszkańcy wioski porzucali w panice swoich chorych bliskich, pozbawiając ich opieki i skazując na śmierć. Bohannan zaś, podejrzewana o czarownictwo, musiała uciekać wraz z innymi, gdyż pozostanie $\mathrm{w}$ wiosce potwierdziłoby te podejrzenia i naraziło na utratę życia. Jej ucieczka, wywołana lękiem i konformizmem, była negacją przyjmowanych przez nią norm i wartości, które nakazują niesienie pomocy osobom dotkniętym chorobą. To zdarzenie wywołało u niej dezintegrację pozytywną ${ }^{48}$, zrozumiała bowiem, że nie można poddawać się naciskom grupy, a także „eklektyczne wybierać dla siebie wygodnych moralnych maksym”, gdyż skutkuje to naruszeniem własnej integralności ${ }^{49}$.

\footnotetext{
46 P. Rabinow, Refleksje na temat badań..., s. 131.

47 L. Bohannan, Return to Laughter, s. 224.

48 K. Dąbrowski, Dezintegracja pozytywna, Warszawa 1979.

49 L. Bohannan, Return to Laughter, s. 291.
} 
Nie tylko jednakże proces badawczy ma swoje zaskakujące zwroty. Zmianie ulega także tożsamość badacza, który, zgodnie z hermeneutycznym kołem, poszerza rozumienie siebie samego w konfrontacji z Innym, gdyż „'ja’ ma publiczna naturę, historycznie i społecznie zmediatyzowaną"50. Jak słusznie zauważa Stoller, antropolog nigdy tak naprawdę nie odchodzi z pola badań, ludzie i zdarzenia zmieniają go jako osobę, niekiedy tak głęboko, że możemy mówić o epifanii. Tak było waśnie w przypadku Stollera, który początkowo traktował swoje „lekcje magii” z dystansem i wyłącznie dla celów badawczych, z czasem jednak okazało się, że odkrywa w sobie moc rzucania czarów i przeganiania złych duchów. Jego tożsamość antropologa została poddana w wątpliwość i pojawiły u Stollera poważne dylematy tożsamościowe. Przestał być niezależnym obserwatorem, a stał się uczniem czarowników i skutecznym praktykantem magii. To było bardzo trudne do pogodzenia jego akademickim habitusem i racjonalnością zachodniej cywilizacji. W końcu powrócił do swojej rodzimej kultury, ale motywowany raczej poczuciem strachu przed klątwą czarownicy, która mściła się na nim za złe potraktowanie jej syna niż z powodu odrzucenia wiary w afrykańska magię. Stał się sorko benya (niewolnikiem sorko) i do końca narracji nie wyrzekł się tej roli.

\section{Zakończenie}

Role odgrywane przez antropologów w polu badawczym wynikają z wielu czynników i są wypadkową epistemologicznych i metodologicznych wyborów, strukturalnych oraz sytuacyjnych ograniczeń i potencjalności, a także idiosynkratycznych cech osobowych badaczy. Etnografowie są obcymi w polu badań nie dlatego, że nikt ich nie zna, ale dlatego że członkowie społeczności lokalnej postrzegają ich jako osoby, które czasowo przebywają "nie na swoim miejscu”" ${ }^{1}$. Ich obecność w polu badawczym nie jest oczywista, nawet jeśli poddani są wstępnej typologizacji, ich kategoryzacje, role, jakie odgrywają stale podlegają negocjacji, w których biorą udział zarówno sami badacze, jak i tubylcy. Niemniej jednak zastany układ ról i statusów sprawia, że projekty badawcze mogą ulegać zmianie. W skrajnych przypadkach, jak było to z Briggs, jej pierwotna tematyka badań (szamanizm) musiała ulec porzuceniu. Dlatego też umiejętność nawiązywania kontaktów, empatyczne identyfikowanie się i komunikowanie z różnymi osobami jest warunkiem sukcesu w badaniach terenowych. Jednakże problemy wynikające z realizacji tych działań nie należy traktować jak porażki, ale wykorzystać jako dane, które przyczyniają się do pogłębionej refleksyjności i krytycyzmu ${ }^{52}$.

${ }^{50}$ P. Rabinow, Refleksje na temat badań terenowych $w$ Maroku, tłum. K.J. Dudek i S. Sikora, Kęty 2010, s. 34 .

51 S. Ahmed, Strange Encounters: Embodied Otherness in Post-Coloniality, London 2000, s. 22.

52 S. Venkateswar, Strategies of Power: An Analysis of an Encounter in the Andaman Islands, „Qualitative Inquiry” 2001, $\mathrm{nr} 7(4)$, s. 448-465. 
Realizując własne schematy biograficzne i dostosowując je do istniejących lokalnych wzorców instytucjonalnych badacz dokonuje pracy nad sobą. Może się zdarzyć, że straci on na pewien czas kontrolę nad własną tożsamością, jak to dzieje się w przypadku „stubylczenia”. Skutkiem tak gwałtownych punktów zwrotnych w biografii może być czasowe zawieszenie czy wzięcie w nawias przyjętych założeń ontologicznych i metodologicznych dotyczących rzeczywistości kulturowej, metafizycznej iluminacji czy epifanii. Bez względu na to, jaki porządek normatywny badacz zastanie w terenie badań, jak bardzo uda się zrealizować cele badawcze, na ile sama persona anthropologica zmieni się pod wpływem zdarzeń trzeba pamiętać o tym że gdy badamy kultury, zawsze robimy to poprzez relację $\mathrm{z}$ innymi osobami, relację, u podstaw których fundamentalna zasada nakazująca uznanie podmiotowości Innego.

Trzeba pamiętać, że etnografia jest nie jest działaniem wolnym od moralnej odpowiedzialności za innych i za swoje dzieło. Badacz nawiązuje w polu badawczym liczne kontakty z innymi ludźmi, które są znormatywizowanymi relacjami. Normy badacza i normy lokalne nie muszą być współmierne i często takie nie są, co prowadzi do dylematów moralnych, które badacz musi rozwiązać. Nawiązywanie przyjacielskich kontaktów wiąże się z poważnymi dylematami etycznymi ${ }^{53}$. Są one tym większe, im bliższe są relacje nawiązywane przez etnografów $z$ badanymi ${ }^{54}$. Badani mogą oczekiwać, że nawiązana $\mathrm{z}$ antropologiem relacja będzie trwała i trudno im zaakceptować, że czas trwania bliskich relacji jest ograniczony czasem trwania badań. Często także bardziej niż badacze emocjonalnie angażują się w budowanie relacji. Bardzo ważny jest także fakt, że etnografowie są powiernikami osobistych sekretów i nie jest moralnie oczywiste, czy te zwierzenia można włączyć w zbiór danych bez poczucia winy, że nadużywa się zaufania i zdradza się swoich rozmówców, nie odbiera im podmiotowości i traktuje instrumentalne, jedynie jako źródło danych ${ }^{55}$.

${ }_{53}$ E. Nowicka, Antropolog wobec innych i wobec siebie. Niektóre problemy etyczne uprawiania antropologii, „Przegląd Socjologii Jakościowej” 2016, nr 3, s. 40-53.

${ }^{54}$ A. Oakley, Interviewing women: a contradiction in terms?, w: Doing Feminist Research, red. H. Roberts, London 1981, s. 30-61.

${ }_{55}$ J. Zalewska, Antropolożka wobec sacrum i przyjaźni w terenie. Badania wśród chrześcijan „żyjących jak w czasach Jezusa” w Sydney w Australii, „Kultura Współczesna” 2005, nr 3 (45), s. 152-166. 